\title{
A bélflóra hematológiai vonatkozásai
}

\author{
Szerafin László dr. - Jakó János dr. \\ Szabolcs-Szatmár-Bereg Megyei Kórházak és Egyetemi Oktatókórház, Jósa András Oktatókórház, \\ Hematológiai Osztály, Nyíregyháza
}

\begin{abstract}
A bélflóra és a különböző betegségek (elhízás, diabetes mellitus, metabolikus kórképek, allergiás és autoimmun betegségek, gyulladásos bélbetegségek, májelégtelenség, infekciók, egyes neuropszichiátriai kórképek, daganatok) közötti összefüggés vizsgálata az utóbbi években előtérbe került. A mikrobióta depléciója gátolja a csontvelői vérképzést. Az infekciók és azok antibiotikumkezelése szintén hatással lehet a vérképzésre. A bélflóra a graft-versus-host betegség súlyosságát is befolyásolhatja és a T-regulátor sejteken keresztül szerepet játszhat az immunthrombocytopenia patogenezisében is. A dolgozat összefoglalja a bélflóra jellemzőit, a mikrobiótának a csontvelői vérképzésre, az infekciók lefolyására, az allogén csontvelő-transzplantációra, a graft-versus-host betegségre, a lymphomák kialakulására gyakorolt hatását, az ezzel kapcsolatos kutatások eredményeit és a terápiás lehetőségeket. Röviden tárgyalja a bélflóra és az immunthrombocytopenia, valamint a daganatok immunterápiájának eredményessége közötti lehetséges kapcsolatot és hatását a von Willebrand-faktor-szintézisre. Felhívja a figyelmet a mikrobiótadiverzitás fenntartásának fontosságára.
\end{abstract}

Orv Hetil. 2019; 160(20): 774-779.

Kulcsszavak: bélflóra, vérképzés, graft-versus-host betegség, lymphomák, immunterápia, bélflóra-diverzitás

\section{Haematological aspects of the gut flora}

The relationship between the gut flora and various diseases (obesity, diabetes mellitus, metabolic disorders, allergic and autoimmune diseases, inflammatory bowel diseases, liver failure, infections, certain neuropsychiatric disorders, tumors) has been highlighted in recent years. Depletion of microbiotics inhibits bone marrow healing. Infections and their antibiotic treatment may also affect hematopoiesis. Intestinal flora may also affect the severity of the graft-versus-host disease and may also play a role in the pathogenesis of immunthrombocytopenia through the T-regulator cells. The study summarizes the features of the gut flora, the effects of microbiotics on bone marrow healing, the course of infections, allogeneic bone marrow transplantation, graft-versus-host disease, lymphoma and the results of related research and therapeutic options. The authors briefly discuss the possible linkage between intestinal flora and immunthrombocytopenia and the effectiveness of the immunotherapy of tumors and its effect on the von Willebrand-factor synthesis. They draw attention on the importance of maintaining microbiotics diversity.

Keywords: intestinal flora, hematopoiesis, graft-versus-host disease, lymphomas, immunotherapy, gut flora diversity Szerafin L, Jakó J. [Haematological aspects of the gut flora]. Orv Hetil. 2019; 160(20): 774-779.

(Beérkezett: 2019. január 3.; elfogadva: 2019. január 25.)

\section{A Szerkesztöség felkérésére készült tanulmány.}

\section{Rövidítések}

aGVHD = (acute graft-versus-host disease $)$ heveny graft-versus-host betegség; ASCT $=$ (allogen stem cell transplantation $)$ idegen donoros csontvelői ôssejt átültetése; CTLA4 = (cytotoxic T-lymphocyte-associated antigen 4) citotoxikus T-lymphocytához társult antigén-4; DNS = dezoxiribonukleinsav; FFA = (free fatty acid) szabad zsírsav; HR = (hazard ratio) kockázati arány; IBD $=$ (inflammatory bowel diseases $)$ gyulladásos bélbetegségek; IFN = interferon; IL = interleukin; LPS = lipopoliszacharidok; MALT $=$ (mucosa-associated lymphoid tissue $)$ mucosához társult lymphoid szövet; MAMPS = (microba-asso- ciated molecular patterns) mikrobára jellemzó molekuláris mintázat; $\mathrm{MHC}=($ major hystocompatibility complex $)$ fó hisztokompatibilitási komplex; MYD88 = (myeloid differentiation primary response 88 ) myeloid differenciációs elsődleges válasz gén-88; $\mathrm{NF} \kappa \mathrm{B}=$ nukleáris faktor kappa-B; $\mathrm{NOD}=$ (nucleotidebinding oligomerisation domain) nukleotidkötő oligomerizáló domén; NODLL = (nucleotide-binding oligomerisation domain-containing protein-1 ligand) nukleotidkötő oligomerizáló domént tartalmazó protein-1 ligand; PDl = (programmed cell death 1) programozott sejthalál-1; rRNS = riboszomálisribonukleinsav; STATl $=$ (signal transducer and 
activator of transcription 1) szignalizációs transzducer és transzkripcióaktivátor- 1 ; TGF $\beta=$ (transforming growth factor beta) transzformáló növekedési faktor-béta; Thl7 = T-helper-17 (sejt); TLR = (Toll-like receptor) Toll-szerü receptor; $\mathrm{TNF}=$ (tumor necrosis factor) tumornekrózis-faktor; Treg = regulatorikus T-sejt; vWf $=$ von Willebrand-faktor

\section{A bélflóra élettani jellemzői}

A bélflóra (bélmikrobióta) olyan mikroorganizmusfajok komplex közössége, amely az állatok és az ember tápcsatornájában él. A széklet szárazanyag-tartalmának 60\%-át teszi ki. Kb. 100 billió baktérium (az emberi test saját sejtjeinek kb. 1,3-10×-ese, 1-2 kg), 300-1000 faj alkotja, génjeik száma az emberi genom kb. 150×-ese. A baktériumok mennyisége, faji megoszlása a tápcsatorna egyes szakaszain különböző (a csíraszám a colonban a legmagasabb). A bélflóra baktériumai luminalisan és a bélnyálkahártyához kötődve helyezkednek el. A fóbb baktériumtörzsek: Gram-negatív Bacteroides-fajok, Gram-pozitív Firmicutes-fajok. A bélflórát nagyfokú diverzitás jellemzi, amely függ az étrendtől (egy adott enterotípus túlsúlya utal a táplálék összetételére), a földrajzi elhelyezkedéstől (a baktériumflóra diverzitása változó, a Firmicutes-fajok túlsúlya és a Bacteroidesek mennyiségének csökkenése fokozott energiahasznosulással jár, ami elhízást okoz), az életkortól (a bélbaktérium kolonizációja a szülés idején kezdődik, ezt a császármetszés késlelteti, ami hatással lehet az immunrendszer kialakulására és a későbbiekben az ezzel kapcsolatos betegségek előfordulására; az idősekben nagyobb individuális különbségek lehetnek), a közösség helyi viszonyaitól (kórházi ápoltakban a bélflóra kevésbé változatos, ami elősegítheti különböző infekciók jelentkezését), a cirkadián ritmustól (a mikrobióta a cirkadián ritmus szétzilálása esetén megváltozhat). A helytelen diéta, a stressz, az antibiotikumok, a szteroidok, a nemszteroid gyulladásgátlók, a protonpumpagátlók előnytelenül befolyásolják a bélflóra összetételét $[1,2]$.

\section{Az egészséges bélflóra funkciói}

A bakteriális mikrobióta biztosítja a bélnyálkahártya integritását (barrierfunkció). Védi a szervezetet a patogén mikroorganizmusok behatolásától. Az emészthetetlen rostokat emészthetővé teszi, ami energiatermelést eredményez, a rövid láncú szabad zsírsavak termelődését fokozza. A bélbaktériumok B- és K-vitaminokat termelnek, fontos szerepük van a másodlagos epesavak képzésében (immunmoduláns hatás). A mikrobiótának alapvető szerepe van a veleszületett és a szerzett immunitás kialakulásában (kb. 80\%-ban meghatározza, amelyben a T-sejteknek központi szerepük van). Szerepet játszik az idegrendszer fejlődésében és a viselkedés alakulásában (agy-béltengely kétirányú kapcsolat, agy-bél-immunrendszer háromirányú kapcsolat, kémiai közvetítőkön
- triptofán-anyagcsere, oxitocin, brain-derived-neurotrophic factor [agyi eredetú növekedési faktor] - és a vagusidegen keresztül) [1-4].

\section{Dysbiosis}

Az emberrel szimbiózisban élő baktériumok abnormális állapota a bélben, a hüvelyben vagy a bőrön különböző betegségek kialakulásához vezet. A dysbiosis a bélbaktériumok összetételének megváltozása a patogén baktériumok túlszaporodása miatt. A vékonybél-baktériumok túlszaporodása, a szervezet immunitásának csökkenése vagy a bélpermeabilitás fokozódása következtében transzlokáció útján a baktériumok a mucosán keresztül elhagyják a bél lumenét, és bejutnak a szervezetbe (a hasznos baktériumok is ártalmasak lehetnek a bélrendszeren kívül). Fontos szerepük van az antimikrobiális fehérjéknek, amelyek a bélmikrobióta összetételének szabályozói. A bélmikrobióta összetételében fellépő változások endotoxinok beáramlását segítik elő a szervezetbe. A Gram-negatív baktériumok külső membránjának lipopoliszacharidjai (LPS), az endotoxinok gyulladásos folyamatokat indítanak el $[1,2]$.

\section{A dysbiosissal kapcsolatos betegségek}

A legtöbb irodalmi adat a bélflóra metabolikus betegségekkel való kapcsolatával (obesitas, metabolikus szindróma, inzulinrezisztencia, nem alkoholos zsírmáj) foglalkozik. A mikrobióta összetételének lényeges szerepe van a táplálék hasznosulásában. A zsírdús diéta a Firmicutesfajok túlszaporodását és a Bacteroidesek csökkenését okozza, ami növeli a plazma LPS-koncentrációját (metabolikus endotoxaemia), s ez a Toll-like receptor (TLR4, -3) aktivációja útján krónikus szisztémás gyulladást okoz, amely inzulinrezisztenciához vezet. Az emészthetetlen szénhidrátok bélbaktériumok általi fermentációja energiatermelést eredményez, valamint rövid láncú szabad zsírsavak képződnek (FFA: butirátok, proprionátok, acetátok), amelyek felszívódva a zsírszövetben és a $\beta$-szigetsejtben aktiválják a szabadzsírsav-receptor-2-t és -3-at. Ez hisztondeacetilálást idéz elő, és fokozza a $\beta$-sejt-proliferációt, -differenciációt, a glükagonszerű peptid-1 szekrécióját, ami inzulinfelszabadulást okoz. A zsírszövetben proinflammatoricus citokinek termelődnek, ezek hatására megváltozik a leukocytaaktiváció, s ennek következtében a glükózfelvétel fokozódik, az inzulinrezisztencia csökken [1, 2, 5-7].

Számos adat szól a gyulladásos bélbetegségek (IBD), az autoimmun betegségek (köztük az immunthrombocytopenia), az allergiás kórképek és a megváltozott bélflóra közötti kapcsolatról [1, 3]. A neuropszichiátriai betegségek közül a Parkinson-kór, a depresszió, az autizmus, a sclerosis multiplex, a myoclonusdystonia és a krónikusfáradtság-szindróma hozható kapcsolatba a dysbiosissal $[1,4]$. Egyes daganatok kialakulása és a bélflóra közötti összefüggésrőll is vannak adatok. A bélflórának a 
metabolikus betegségek kialakulásában betöltött szerepéről magyar nyelven Halmos és mtsa [2], a hypertoniával való összefüggéséról Barna és mtsai [8], a bélflórának a májbetegségekben betöltött szerepéről Hagymási és mtsai [9], a bélflóra és a mentális betegségek közötti öszszefüggésekról Frecska és mtsa [4] adtak magyar nyelven részletes irodalmi áttekintést.

\section{Vérképzés és a bakteriális mikrobióta}

\section{A bélflóra (mikrobióta) mennyiségi és minöségi csökkenésének hatása a vérképzésre egérben}

Csíramentes egerekben kisebb a haemopoeticusőssejt- és progeritorsejt-populáció, kóros a lép-myeloidsejtszám, károsodott a T-sejt-múködés. A bélbaktériumok menynyiségének csökkentése orális antibiotikumokkal a csontvelői haematopoesis szuppresszióját okozta, a transzplantált haemopoeticus ôssejteket károsította.

\section{Dysbiosissal társult vérképzés-szuppresszió emberben}

Obesitasban, malnutritióban, táplálkozási betegségekben, gyulladásos bélbetegségekben a megváltozott mikrobióta gyulladásos környezetet indukál, amely haemopoeticus abnormalitásokhoz (anaemia, neutropenia, thrombocytopenia, pancytopenia) vezet. A béta-laktám antibiotikumok, a penicillin-G a betegek 5-15\%-ában neutropeniát okoz (nem korlátozódik egyetlen antibiotikumcsoportra). A trimetoprim folsavantagonista hatása miatti neutropenia $\mathrm{kb}$. $100 \times$ ritkább, mint az egyéb el- húzódó antibiotikumkezelés okozta neutropenia. A bélmikrobióta számának és diverzitásának csökkenése gátolja a transzplantátum megtapadását, fokozza a leukaemia relapsuskockázatát, az aGVHD (acute graft-versus-host disease) okozta és a transzplantációs halálozást. Az antibiotikum okozta neutropenia fokozza az opportunista és potenciálisan végzetes fertőzések kockázatát. A hosszas antibiotikumkezelés a vérképzés szuppresszióját okozza. $\mathrm{Az}$ antibiotikumok terápiás dózisban, rövid ideig adva nincsenek hatással az össejtkolónia-képzésre (in vitro). A vérképzés csökkenésének okaként felmerültek az immunmediált mechanizmusok: vankomicinhez társult thrombocytopenia, antipenicillin-antitestek, de ilyen hatások nem rontják az ismételten adott penicillin hatását. A granulocyta- és monocytaszám csökkenése csíramentes vagy antibiotikummal kezelt egerekben megakadályozható bélmikrobiótából származó MAMPS (microba-associated molecular patterns: Escherichia coli hörezisztens komponens szérumban, nucleotide-binding oligomerisation domain-containing protein-1 ligand [NODlL]) orális bevitelével vagy normálmikrobióta rekolonizációjával $[1,10]$.

ran és mtsai [10] az alábbi modellt javasolják a vérképzést elősegítő, mikroba kiváltotta szignálkaszkádra. A mikroba metabolikus termékek (MAMPS) a stromasejtekben aktiválják a TLR4 $\rightarrow$ MYD88+ (myeloid differentiation primary response 88) NODl szignálutat, ami I. típusú interferontermelést vált ki. Ez a haemopoeticus progenitor őssejtekben STAT1 - (signal transducer and activator of transciption 1) aktivációt okoz, a haemopoesist is elősegítő génprofil aktiválását előidézve (1. ábra). Összefoglalva: egérkísérletek alapján a mikro-

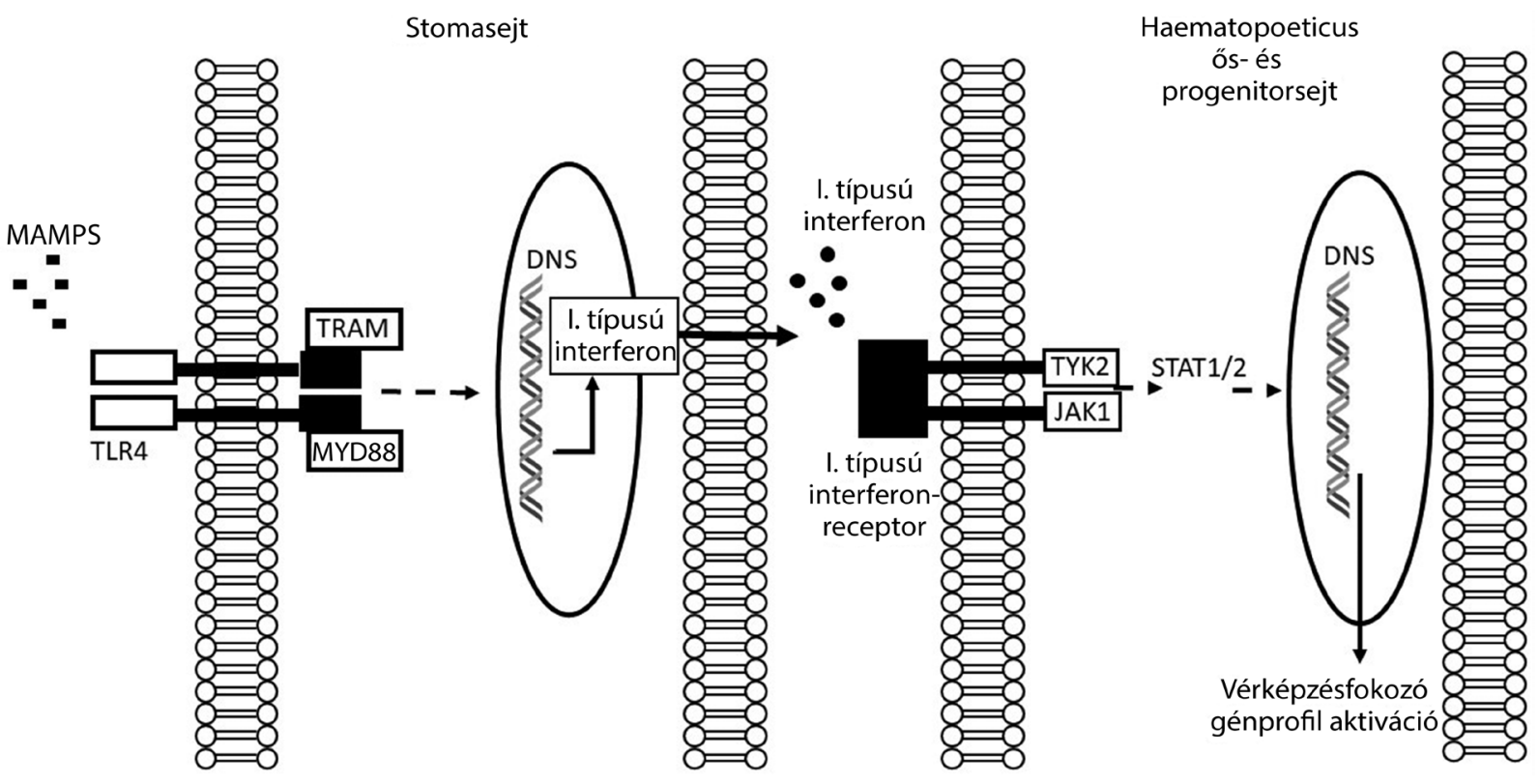

l. ábra $\quad$ A mikrobiótaszignál vérképzést elősegítő feltételezett hatása (sematikus modell H. Yan után)

JAKl = Janus-kináz-1; MAMPS = mikrobára jellemző molekuláris mintázat; MYD88 = myeloid differenciációs elsődleges válasz gén- $88 ;$ STATl $/ 2=$ szignalizációs transzducer és transzkripcióaktivátor $1 / 2$; TLR4 = Toll-szerú receptor-4; TRAM = TRIF-related adaptor molecule; TYK2 = tirozinkináz-2 
bióta antibiotikum okozta mennyiségi és minőségi csökkenése és a csontvelő-szuppresszió oka a hőstabil mikrobatermékek hiánya, amelyek a véráramban keringenek, és egy lokális gyulladásos szignálon keresztül elősegítik a vérképzést. Ezért kerülendő a bélmikrobióta mennyiségét és diverzitását csökkentő hosszas, indokolatlan antibiotikumkezelés.

\section{A bélmikrobióta szerepe az allogén haemopoeticus őssejtek transzplantációjában és a graft-versus-host betegségben}

\section{A mikrobióta és az immunitás kialakulása}

A bakteriális mikrobiótának a veleszületett és a szerzett immunitás kialakulásában egyaránt meghatározó szerepe van. Csíramentes egerekben mikrobiótaexpozíció után 4 nappal a TNF $\alpha$ (tumor necrosis factor), az IFN $\gamma$ (interferon) és a MHCI (major hystocompatibility complex) szintje emelkedik (veleszületett immunitás), az adaptív immunitás kialakulásában játszott szerepére pedig a 8 nap után emelkedő MHCII-molekulák és T-sejtek száma utal. A Treg- (regulatorikus T-sejt) sejtek száma (amely az IL10- [interleukin] és a TGFß-szint [transforming growth factor beta] emelkedéséhez vezet) és a Th17 (Thelper-17)-sejtek száma (hatásukra az IL17-, IL22-expresszió fokozódik) emelkedik, ezek az antigénekre adott immunválasz alapjai.

Az étkezési rostok lebontása során keletkező metabolitok termelése, a rövid láncú zsírsavak (vajsav, propionát, acetát) nemcsak energiatermelést jelentenek a bélhámsejtek számára, hanem védő, szabályozó immunválaszt is előidéznek a bélben és szisztémásan [3, 11-13].

\section{A dysbiosis oka ASCT (allogen stem cell transplantation) és aGVHD esetén [11-13]}

- Antibiotikumkezelés őssejttranszplantáció során.

- Kondicionáló kezelés és kemoterápia.

\section{A dysbiosis következményei}

A baktériumdiverzitás elvesztése miatt nő a Clostridium difficile-fertőzés kialakulásának veszélye. Az aGVHDben a Firmicutes-fajok száma emelkedik, a Bacteroidetesfajoké csökken. A Clostridium cluster XIV/Blautia, Lactobacillus mennyisége csökken, az Enterococcusoké emelkedik. A Clostridium-fajok rövidláncú zsírsav-termelése diétás rostokból csökken, a butiráttermelődés szintén.

A kialakuló bélfalkárosodás következtében a bélfal permeabilitása nő, a baktériumok átjutása a bélfalbarrieren fokozódik, ami LPS, peptidoglikánok véráramba jutását segíti elő, ez pedig gyulladásoscitokin-választ indukál. Emiatt az infekciók gyakorisága, súlyossága foko- zódik. A TLR4 és NOD2 receptorokon keresztül T-sejtalloaktiváció következik be, ami az aGVHD súlyosságát fokozza [11-20].

\section{Klinikai tapasztalatok}

Széles spektrumú antibiotikumok (imipenem-cilasztatin/piperacillin-tazobaktám) alkalmazása növeli az 5 éves, GVHD okozta halálozást, a súlyos GVHD előfordulását ( $42 \%$ versus $28 \%$ ), a súlyos GVHD okozta összhalálozást (HR: 1,83). A transzplantáció előtt adott korai antibiotikumkezelés független faktora a teljes halálozásnak (HR: 2,0). A diverzitás elvesztése növeli a kezeléssel összefüggő GVHD-, fertőzések és szervkárosodás okozta halálozás kockázatát [11]. Az új generációs szekvenálási technikával, a 16rRNS- (riboszomális ribonukleinsav) szekvenálással [1], valamint a mindennapi gyakorlatban is alkalmazható, a bélbaktériumok által termelt 3-indoxil-szulfát vizeletben történő mérésével [21] meghatározható a bélflóra diverzitása. A bélbaktériumok termelte indolszármazékok az I. típusú interferon (IFN1) szignálgénjeinek aktivációja útján csökkentik a myeloablativ kemoterápia, sugárzás és az aGVHD okozta bélgyulladást és bélkárosodást, de megörzik a daganatellenes reakciót, ugyanakkor az aGVHD okozta halálozás mérséklődik [21]. A csökkent mikrobiótadiverzitás összefüggést mutat a Treg/Th17 egyensúllyal [22]. A transzplantáció előtt $>5 \%$ proinflammatoricus Enterobacteriaceae az egyetlen szignifikáns markere a szepsis kockázatának. <10\% Lachnospiraceae az egyetlen szignifikáns előrejelzője az összhalálozás kockázatának. Az alacsony baktériumdiverzitás a transzplantációt követő 10. napon az egyetlen szignifikáns változó, amely összefüggést mutat a 30 napon belüli súlyos GVHD kockázatával [23]. A súlyos aGVHD összefüggést mutatott a Panethsejtek csökkent antimikrobiálispeptid-expressziójával a vékonybélben [18].

\section{Megelözés [12, 24-27]}

A kísérletes megfigyelések és klinikai tapasztalatok alapján a súlyos aGVHD megelőzésére az alábbiak javasolhatók:

- A korai antibiotikumkezelés elkerülése [12].

- Bélből nem felszívódó rifaximin adása [12, 24].

- Az enteralis táplálás előnyben részesítése a parenteralis táplálás helyett transzplantációt követően [12].

- Pre- (pro-)biotikumok adása (elsősorban a Lactobacillusok számának növelése célszerü, de a pH-érzékenység befolyásolja a hatásukat) [12].

- Székletmikrobióta-transzplantáció (kedvező, a kis esetszámú klinikai tanulmányok eredményei biztatóak, de a hatásosság és biztonságosság megítéléséhez további adatgyứjtés szükséges) [12, 25-27]. 


\section{Bélbaktériumok okozta lymphomák [28]}

A mikrobióta és a lymphomák közötti összefüggést először állatmodellekben igazolták. A MALT- (mucosa-associated lymphoid tissue) lymphomák és a Helicobacterfertőzés közötti erős kapcsolat már régóta ismert. A MALT-lymphomák kb. 90\%-a Helicobacter-fertőzéshez társul, amelynek eradikációja az esetek kb. 80\%-ában komplett remissziót eredményez. Egyéb baktériumok, amelyek szerepet játszhatnak a lymphomák kialakulásában: Campylobacter jejuni, Borrelia burgdorferi, Chlamydia psittaci, Streptococcus bovis.

\section{A mikrobióta indukálta lymphoma kialakulásának mechanizmusa állatmodellekben}

1. A mikrobióta közvetlenül elindíthatja a lymphomagenesist. Egyes bélbaktériumok közvetlenül okozhatják a mutagének és az oxidatív stressz fokozódását vagy semlegesítését, ezek a DNS (dezoxiribonukleinsav) károsodásához és következményes daganat kialakulásához vagy annak gátlásához vezetnek. A baktériumok közvetlen interakciója az immunsejtekkel oxidatív stresszt vagy nekrózist és $\mathrm{NF}_{\kappa} \mathrm{B}-$ (nuclearis factor kappa B) gátlást okoz, amelyek DNS-károsodást okozva elindíthatják a carcinogenesist. A baktériumok antigénként az immunsejtek krónikus proliferációját is stimulálhatják (például H. pylori állandó antigénprezentáció B-sejt-expanzióhoz vezet).

2. A mikrobióta megváltoztathatja a lymphoma kialakulására ható paramétereket. A csíramentes egereken végzett kísérletek bizonyítják, hogy a bélmikrobióta nélkülözhetetlen a normális immunrendszer fejlődéséhez. A baktérium okozta T-sejt-aktivitás-változás, IL10-, IL17-, IFN $\gamma$-, Th17-válasz fokozódása szükséges a tumorképződéshez. Az immunsejt-populációban történő változás a TNF $\alpha$ és TNF $\gamma$ gyulladásos útvonal aktivitását növeli. Ugyanakkor a mikrobióta védőhatású is lehet a daganatsejttel szemben. Csökkentett mikrobiótájú egérben a citotoxikus T-sejt-aktivitás-fokozódás, a CD8+ Tsejt-szám-emelkedés daganatokkal szembeni védőhatását tapasztalták.

A tejsavbaktériumok védőhatásúak a carcinogenesissel szemben, mert az oxidatív stresszt és gyulladást csökkentik, és a rostok bakteriális fermentációja során képződő vajsav (rövid láncú zsírsav) hatására a Treg-sejtek specifikációja és expanziója fokozódik.

Összefoglalva: a mikrobióta direkt/indirekt hatása az immunsejtekre lymphocytaproliferációt okoz, ami növeli a kóros DNS-osztódás veszélyét (fóleg a sérülékenyebb és genetikailag instabilabb B-sejtekben). A mikrobióta által direkt vagy az immunrendszeren keresztüli indirekt oxidatív stressz is fokozza a carcinogenesis valószínúségét. Egyes bélbaktériumok viszont jótékony hatásúak az egészségre (Lactobacillus), míg mások kórosak lehetnek (Helicobacteriaceae).

\section{Az immunthrombocytopenia és a bélflóra $[3,7,29]$}

Irodalmi közlések szerint a széklettranszplantáció autoimmun betegségekben kedvező lehet (rheumatoid arthritis, szisztémás lupus erythematosus, Sjögren-szindróma, Hashimoto-thyreoiditis). Pro- és prebiotikumok adása, a bélflóra összetételének megváltoztatása annak metabolitjai révén (például rövid láncú zsírsavak) Tregsejt-indukciót eredményez. (A szimbiózisfaktor, például poliszacharid-A, a TLR2 aktiváció útján az IL10-termelődés fokozódásához vezet). Egy esetismertetés szerint egy immunthrombocytopeniás betegnél a colitis ulcerosa miatt végzett széklettranszplantáció a thrombocytaszám normalizálódását eredményezte [30]. (E közleménynek nem tárgya a $H$. pylori-fertőzés és az immunthrombocytopenia, valamint az atrophiás gastritis okozta vérszegénység tárgyalása, mivel ezeknek nagy irodalmuk van, amely meghaladja a jelen közlemény kereteit.)

\section{A bélflóra hatása az immunterápiára [31-33]}

A bélflóra összetétele hatással van az immunterápia (CTLA4- [cytotoxic T-lymphocyte-associated antigen 4] és PDI - [programmed death 1] gátlók) eredményességére egyes irodalmi adatok szerint. A normális bélflóra baktériumainak túlsúlya (Bacteroides, Bifidobacterium, Firmicutes) fokozza az immunterápia hatékonyságát. Ez esetben is fontosnak tünik a bélflóra nagyobb fokú diverzitása [32]. Ennek hátterében a bélflóra immunmoduláns hatása állhat. Az eddigi adatok még ellentmondásosak, a kérdés kritikus megközelítése, további adatgyưjtés szükséges az e kérdésben történő végleges állásfoglaláshoz.

\section{A bélflóra-mikrobióta szabályozza a máj von Willebrand-faktor-szintézisét és az arterialis thrombusképződést a Toll-szerú receptor-2 útján [34]}

Csíramentes és TLR2-hiányos egerek arteria carotis sérülést követô thrombusnövekedése csökkent a kontrollokéhoz képest, amelyekhez viszonyítva a plazma-vW (von Willebrand)-szintnek és a májendothelsejtek vWfaktor szintézisének a csökkenését észlelték. Mikrobiótakolonizáció megszüntette a thrombusnövekedés különbségét a genotípusok között. A mikrobióta indukálta TLR2-szignál megváltoztatja a májendothelium vW-faktor-szintézisét, és elősegíti a thrombocyta integrinfüggő thrombus képződését.

Anyagi támogatás: A szerzők anyagi támogatásban nem részesültek. 
Szerzôi munkamegosztás: Sz. L.: Témafelvetés, irodalomgyưjjtés, a dolgozat megírása. J. J.: A dolgozat megírása. A cikk végleges változatát mindkét szerző elolvasta és jóváhagyta.

\section{Érdekeltségek: A szerzőknek nincsenek érdekeltségeik.}

\section{Irodalom}

[1] Young VB. The role of the microbiome in human health and disease: an introduction for clinicians. Br Med J. 2017; 356: j831.

[2] Halmos T, Suba I. Physiological patterns of intestinal microbiota. The role of dysbacteriosis in obesity, insulin resistance, diabetes and metabolic syndrome. [A bélbakterióta élettani jellemzői, a dysbacteriosis szerepe az elhízásban, inzulinrezisztenciában, diabetesben és metabolikus szindrómában.] Orv Hetil. 2016; 157: 13-22. [Hungarian]

[3] Wu HJ, Wu E. The role of gut microbiota in immune homeosta sis and autoimmunity. Gut Microbes 2012; 3: 4-14.

[4] Frecska E, Móré Cs. The role of gut microbiota in mental health. [A bélflóra szerepe a mentális egészségben.] Lege Art Med. 2018; 28: 11-15. [Hungarian]

[5] Gomes AC, Bueno AA, de Souza RG, et al. Gut microbiota, probiotics and diabetes. Nutr J. 2014; 13: 60.

[6] Komaroff AL. The microbiome and risk for obesity and diabetes. JAMA 2017; 317: 355-356.

[7] Richards JL, Yap YA, McLeod KH, et al. Dietary metabolites and the gut microbiota: an alternative approach to control inflammatory and autoimmune diseases. Clin Transl Immunol. 2016; 5: e82.

[8] Barna I, Nyúl D, Szentes T, et al. Review of the relation between gut microbiome, metabolic disease and hypertension. [A bélmikrobiom, a metabolikus betegségek és a hypertonia kapcsolatának irodalmi áttekintése.] Orv Hetil. 2018; 159: 346-351. [Hungarian]

[9] Hagymási K, Bacsárdi A, Egresi A, et al. The role of gut microbiota in chronic liver diseases, and treatment possibilities. [A bélflóra patofiziológiai jelentősége és szerepe mint terápiás célpont májbetegségekben.] Orv Hetil. 2018; 159: 1465-1474. [Hungarian]

[10] Yan H, Baldridge MT, King KY. Hematopoiesis and the bacterial microbiome. Blood 2018; 132: 559-564.

[11] Routy B, Letendre C, Enot D, et al. The influence of gut-decontamination prophylactic antibiotics on acute graft-versus-host disease and survival following allogeneic hematopoietic stem cell transplantation. Oncoimmunology 2017; 6: el258506.

[12] Staffas A, Burgos da Silva M, van den Brink MR. The intestinal microbiota in allogeneic hematopoietic cell transplant and graftversus-host disease. Blood 2017; 129: 927-933

[13] Weber D, Jenq RR, Peled JU, et al. Microbiota disruption induced by early use of broad-spectrum antibiotics is an independent risk factor of outcome after allogeneic stem cell transplantation. Biol Blood Marrow Transplant. 2017; 23: 845-852.

[14] Zeiser R, Socié G, Blazar BR. Pathogenesis of acute graft-versushost disease: from intestinal microbiota alterations to donor $\mathrm{T}$ cell activation. Br J Haematol. 2016; 175: 191-207.

[15] Tabibian JH, Kenderian SS. The microbiome and immune regulation after transplantation. Transplantation 2017; 101: 56-62.

[16] Yoshioka K, Kakihana K, Doki N, et al. Gut microbiota and acute graft-versus-host disease. Pharmacol Res. 2017; 122: 90-95.
[17] Doki N, Suyama M, Sasajima S, et al. Clinical impact of pre transplant gut microbial diversity on outcomes of allogeneic hematopoietic stem cell transplantation. Ann Hematol. 2017; 96: $1517-1523$.

[18] Weber D, Frauenschläger K, Ghimire S, et al. The association between acute graft-versus-host disease and antimicrobial peptide expression in the gastrointestinal tract after allogeneic stem cell transplantation. PLoS ONE 2017; 12: e0185265.

[19] Riwes M, Reddy P. Microbial metabolites and graft versus host disease. Am J Transplant. 2018; 18: 23-29.

[20] Shallis RM, Terry CM, Lim SH. Changes in intestinal microbiota and their effects on allogeneic stem cell transplantation. Am J Hematol. 2018; 93: 122-128.

[21] Swimm A, Giver CR, DeFilipp Z, et al. Indoles derived from intestinal microbiota act via type I interferon signaling to limit graft-versus-host disease. Blood 2018; 132: 2506-2519.

[22] Han L, Jin H, Zhou L, et al. Intestinal microbiota at engraftment influence acute graft-versus-host disease via the Treg/Th17 balance in allo-HSCT recipients. Front Immunol. 2018; 9: 669.

[23] Mancini N, Greco R, Pasciuta R, et al. Enteric microbiome markers as early predictors of clinical outcome in allogeneic hematopoietic stem cell transplant: results of a prospective study in adult patients. Open Forum Infect Dis. 2017; 4: ofx215.

[24] Ponziani FR, Gerardi V, Pecere S, et al. Effect of rifaximin on gut microbiota composition in advanced liver disease and its complications. World J Gastroenterol. 2015; 21: 12322-12333.

[25] Kakihana K, Fujioka Y, Suda W, et al. Fecal microbiota transplantation for patients with steroid-resistant acute graft-versus-host disease of the gut. Blood 2016; 128: 2083-2088.

[26] DeFilipp Z, Peled JU, Li S, et al. Third-party fecal microbiota transplantation following allo-HCT reconstitutes microbiome diversity. Blood Adv. 2018; 2: 745-753.

[27] Qi X, Li X, Zhao Y, et al. Treating steroid refractory intestinal acute graft-vs.-host disease with fecal microbiota transplantation: a pilot study. Front Immunol. 2018; 9: 2195.

[28] Yamamoto ML, Schiestl RH. Intestinal microbiome and lymphoma development. Cancer J. 2014; 20: 190-194.

[29] Dwivedi M, Kumar P, Laddha NC, et al. Induction of regulatory $\mathrm{T}$ cells: a role for probiotics and prebiotics to suppress autoimmunity. Autoimmun Rev. 2016; 15: 379-392.

[30] Xu MQ, Cao HL, Wang WQ, et al. Fecal microbiota transplantation broadening its application beyond intestinal disorders. World J Gastroenterol. 2015; 21: 102-111.

[31] Derosa L, Routy B, Kroemer G, et al. The intestinal microbiota determines the clinical efficacy of immune checkpoint blockers targeting PD-1/PD-Ll. Oncoimmunology 2018; 7: el434468.

[32] Elkrief A, Derosa L, Zitvogel L, et al. The intimate relationship between gut microbiota and cancer immunotherapy. Gut Microbes 2018 Oct 19. DOI: 10.1080/19490976.2018. 1527167. [Epub ahead of print]

[33] Humphries A, Daud A. The gut microbiota and immune checkpoint inhibitors. Hum Vaccin Immunother. 2018; 14: 21782182.

[34] Jäckel S, Kiouptsi K, Lillich M, et al. Gut microbiota regulate hepatic von Willebrand factor synthesis and arterial thrombus formation via Toll-like receptor-2. Blood 2017; 130: 542-553.

(Szerafin László dr., Nyíregybáza, Szent István út 68., 4400 e-mail: dr.szerafin.laszlo@szszbmk.hu)

A cikk a Creative Commons Attribution 4.0 International License (https://creativecommons.org/licenses/by/4.0/) feltételei szerint publikált Open Access közlemény, melynek szellemében a cikk bármilyen médiumban szabadon felhasználható, megosztható és újraközölhetö, feltéve, hogy az eredeti szerző és a közlés helye, illetve a CC License linkje és az esetlegesen végrehajtott módositások feltüntetésre kerülnek. (SID_1) 